\title{
PENINGKATAN KEMAMPUAN GURU DALAM PENYUSUNAN RENCANA PELAKSANAAN PEMBELAJARAN KURIKULUM 2013 MELALUI BIMBINGAN BERKELANJUTAN
}

\author{
Hadijah, Tb. Sodikin, Budiarjo \\ Mahasiswa Prodi Manajemen Pendidikan Islam \\ Program Pascasarjana UIN Sultan Maulana Hasanuddin Banten \\ Email: hadijahspdi1@gmail.com
}

\begin{abstract}
Abstraksi
Penelitian ini bertujuan untuk mengetahui peningkatan kemampuan guru dalam menyusun Rencana Pelaksanaan Pembelajaran kurikulum 2013 melalui bimbingan berkelanjutan di MTs ASSyifa, MTS Roudhotul Iman dan MTs Nurul Hidayah Sugal, yang berada pada Kecamatan Panimbang Kabupaten Pandeglang Provinsi Banten, Tekhnik pengumpula data dalam penelitian ini adalah observasi dan diskusi, observasi dipergunakan untuk mengumpulkan data dan mengetahui kompetensi guru dalam menyusun RPP, diskusi dilakukan antara peneliti dengan guru, sedangkan alat pengumpulan data dalam PTKP ini sebagai berikut, lembar observasi yang dilengkapi dengan rubrik yang digunakan untuk memperoleh data tentang kemampuan guru dalam menyusun RPP kurikulum 2013 dan diskusi dilakukan dengan maksud untuk sharing pendapat antara peneliti dengan guru dan guru dengan team teaching. Berdasarkan temuan-temuan yang diperoleh dari hasil pengolahan dan analisis data penelitian ini, maka dapat disimpulkan bahwa pembinaan administrasi akademik berupa penyusunan RPP kurikulum 2013 yang baik sangat signifikan. Dengan kata lain melalui pembinaan pengawas kepada guru mampu meningkatkan kemampuan akademik guru dalam bentuk penyusunan RPP kurikulum 2013 dalam mencapai sasaran kinerja
\end{abstract}

Kata Kunci: Guru, RPP, Kurikulum 2013, bimbingan berkelanjutan

\section{Pendahuluan}

Madrasah Tsanawiyah adalah sebuah lembaga formal yang mengelola peserta didik untuk dibina dan dikembangkan sesuai tujuan pendidikan nasional, untuk itu lembaga ini berusaha semaksimal mungkin untuk mewujudkan tujuan tersebut, sehingga seluruh stakeholder pendidikan dituntut untuk dapat mewujudkan hal tersebut.

Madrasah memiliki tugas dan tanggung jawab yang cukup besar dalam mempersiapkan peserta didik yang berkualitas. Sehubungan dengan hal tersebut Volume kerja kepala dan guru sangat besar hal ini sesuai dengan pernyataan Supriadi ${ }^{1}$. menyatakan bahwa :" Kedudukan guru sebagai pembina dan pendidik, mengharuskan dia memiliki kesiapan memberikan solusi bagi permasalahan yang mereka hadapi. Ia dapat saja mengandalkan

${ }^{1}$ Mulyasa, E. 2003. Menjadi Kepala Madrasah Profesional Dalam Konteks Menyukseskan Manajemen Berbasis Sekolah dan Kurikulum Berbasis Kompetensi. Bandung: PT. Remaja Rosdakarya. 
pengalaman, baik dirinya sendiri maupun orang lain, mengambil teori dari buku-buku, atau bahkan mengandalkan intuisi. Hal ini tentu tidak selamanya memuaskan, karena yang dituntut darinya adalah professional kerja yang dapat dijadikan acuan.”

Namun pada kenyataan dilapangan, pemberlakuan kurikulum 2013 tidak seimbang dengan kemampuan dan pemahaman yang ada baik pada tekhnik pelaksanaan maupun pada penerapan secara tekhnis administrasi. Masalah-masalah intern yang ditemukan di tingkat MTs terutama pada wilayah binaan penulis adalah diantaranya pada Standar Kompetensi Penyusunan Rencana Pelaksanaan Pembelajaran (RPP) kurikulum 2013 oleh guru-guru, dari jumlah binaan yang penulis lakukan ada tiga sekolah binaan yang mengalami masalah yang sejenis, diantaranya adalah MTs AS-Syifa, MTS Roudhotul Iman dan MTs Nurul Hidayah Sugal, yang berada pada Kecamatan Panimbang Kabupaten Pandeglang Provinsi Banten, Kenyataan yang terjadi di tiga madrasah ini adalah guru-guru belum memahami manfaat dari penyusunan RPP kurikulum 2013, kurangnya pembinaan dari kepala sekolah dalam membimbing guru terutama dalam menyusun RPP kurikulum 2013, guru belum mengetahui komponen apa saja yang harus dijabarkan dalam penyusunan RPP kurikulum 2013, guru belum memahami bagaimana cara membuat indikator dalam RPP kurikulum 2013, kepedulian guru terhadap penyusunan administrasi masih rendah, kurangnya koordinasi dan konsultasi antara pengawas, kepala sekolah dengan guru keterkaitan dengan administrasi guru dan pemberian motivasi pada guru kurang

Oleh karena itu, melihat kondisi seperti ini maka perlu dilakukan pembinaan dan pembimbingan terhadap guru dalam bentuk bimbingan berkelanjutan yang dilakukan oleh pengawas sehingga guru memiliki kemampuan untuk menyusun RPP. Adapun hasil dari pemberian tindakan berupa kegiatan bimbingan berkelanjutan ini akan dibuat suatu laporan penelitian tindakan dengan judul Peningkatan kemampuan Guru MTs Dalam Menyusun Rencana Pelaksanaan Pembelajaran Kurikulum 2013 Melalui Bimbingan Berkelanjutan Di MTs AS-Syifa, MTS Roudhotul Iman dan MTs Nurul Hidayah Sugal, yang berada pada Kecamatan Panimbang Kabupaten Pandeglang Provinsi Banten (Studi Pada semester genap Tahun Pelajaran 2016/2017.

Tujuan yang hendak dicapai dalam penelitian ini adalah untuk mengetahui peningkatan kemampuan guru dalam menyusun Rencana Pelaksanaan Pembelajaran kurikulum 2013 melalui bimbingan berkelanjutan di MTs AS-Syifa, MTS Roudhotul Iman dan MTs Nurul Hidayah Sugal, yang berada pada Kecamatan Panimbang Kabupaten Pandeglang Provinsi Banten. Adapun Manfaat yang diharapkan dari penelitian ini adalah diharapkan setelah melakukan bimbingan berkelanjutan meningkatkan kemampuan penulis dalam menulis laporan ilmiah, hasil penelitian ini digunakan peneliti sebagai evaluasi bagi guru, kepala juga bagi pengawas sebagai bahan pertimbangan dalam melakukan pembinaan, melengkapi hasanah bacaan perpustakaan di MTs AS-Syifa, MTS Roudhotul Iman dan MTs Nurul Hidayah Sugal, yang berada pada Kecamatan Panimbang Kabupaten Pandeglang Provinsi Banten. memberikan sumbangsih ilmu pengetahuan terutama ilmu pendidikan, meningkatkan kelengkapan administrasi guru dalam penelitian perencanaan pembelajaran, meningkatkan kompetensi dalam menyusun Rencana Pelaksanaan Pembelajaran kurikulum 
2013 dengan lengkap serta menciptakan kesadaran guru tentang tanggungjawabnya terhadap pelaksanaan tugasnya, sebagai panduan mengajar sehingga apa yang diinginkan dalam program tahunan dan semester dapat tersampaikan sesuai jadwal, dan menciptakan kefektipan mengajar bagi guru sehingga mudah untuk mencapai tujuan.

\section{Metodologi Penelitian}

Penelitian tindakan kepengawasan ini dilaksanakan di 3 (tiga) madrasah yaitu MTs AS-Syifa, MTS Roudhotul Iman dan MTs Nurul Hidayah Sugal, yang berada pada Kecamatan Panimbang Kabupaten Pandeglang Provinsi Banten. Ketiga MTs ini hasil evaluasi kepengawasan Tahun 2019 semester ganjil belum secara keseluruhan mempunyai administrasi yang lengkap, pemahaman dan kepedulian guru terhadap pemenuhan administrasi masih rendah, motivasi guru- juga cukup rendah dan pembimbingan dari kepala madrasah juga belum maksimal, sehingga perlu penanganan yang lebih intensif.

Yang menjadi subjek dalam penelitian ini adalah guru-guru dari tiga Madrasah yaitu MTs AS-Syifa, MTS Roudhotul Iman dan MTs Nurul Hidayah Sugal, yang berada pada Kecamatan Panimbang Kabupaten Pandeglang Provinsi Banten (studi pada semester genap Tahun Pelajaran 2019/2020)., sebanyak 30 orang guru, dengan pertimbangan guru-guru yang mengalami tingkat kesulitan tertinggi dalam penyusunan RPP kurikulum 2013. Sedangkan guru lainnya dijadikan sebagai tutor sebaya juga sebagai team teaching dalam kegiatan tiap siklus. Sumber data dalam PTKP ini adalah RRP guru yang sudah dibuat berdasarkan hasil pembinaan akademik oleh pengawas. Tekhnik pengumpula data 8alam penelitian ini adalah observasi dan diskusi.

Metode yang digunakan dalam penelitian ini adalah methode deskriftif, dengan menggunakan tekhnik presentase untuk melihat peningkatan yang terjadi dari siklus ke siklus. "Metode deskriptif dapat diartikan sebagai prosedur pemecahan masalah yang diselidiki dengan menggambarkan/melukiskan keadaan subjek/objek penelitian (seseorang, lembaga, masyarakat, dan lain-lain) pada saat sekarang berdasarkan fakta-fakta yang tampak atau sebagaimana adanya ${ }^{2}$. Dengan metode ini peneliti berupaya menjelaskan data yang peneliti kumpulkan melalui komunikasi langsung atau wawancara, observasi/pengamatan, dan diskusi yang berupa presentasi atau angka-angka.

\section{Hasil Penelitian dan Pembahasan}

\section{A. Hasil Penelitian}

Penelitian ini dilaksanakan sesuai dengan perencanaan yang disusun dengan tahapan sebagai berikut :

\section{Siklus I}

\footnotetext{
${ }^{2}$ Ali, M. 2004. Strategi Penelitian Pendidikan. Bandung: Angkasa.
} 
Berdasarkan pengamatan awal oleh penulis sekaligus pengawas pada 3 MTs, yaitu MTs ASSyifa, MTS Roudhotul Iman dan MTs Nurul Hidayah Sugal, yang berada pada Kecamatan Panimbang Kabupaten Pandeglang Provinsi Banten, sebanyak 30 orang guru, sebagian besar guru belum paham menyusun RPP kurikulum 2013 yang baik, hal ini disebabkan kurangnya informasi yang mereka dapatkan. Sementara ini semua guru tidak menggunakan administrasi akademik yang baik, hanya berdasarkan tekstual dan prosedural saja.

Kegiatan diawali dengan mendiskusikan tentang permasalahan yang dihadapi dalam menyusun RPP kurikulum 2013 yang baik melalui kelompok yang dilanjutkan dengan penyampaian informasi tentang cara menyusun administrasi RPP kurikulum 2013 yang baik serta memberikan contoh model RPP kurikulum 2013 yang baik. Masing-masing kelompok mengkaji contoh model RPP kurikulum 2013 yang baik yang diberikan, kemudian menetapkan format adminstrasi yang baik yang digunakan. Setelah menyepakati format yang digunakan guru mulai menyusun RPP kurikulum 2013 yang baik dalam kelompok sekolah masing-masing. Hasil pengamatan/observasi tentang kemampuan guru dalam menyusun RPP kurikulum 2013 yang baik pada siklus I adalah sebagai berikut :

Tabel .1 Data Hasil Observasi (Siklus I)

\begin{tabular}{|c|c|c|c|c|c|c|c|c|c|c|c|}
\hline \multirow[t]{3}{*}{ No } & \multirow{3}{*}{$\begin{array}{l}\text { Nama } \\
\text { Guru }\end{array}$} & \multicolumn{10}{|c|}{ Aspek yang di observasi } \\
\hline & & \multicolumn{2}{|c|}{$\begin{array}{c}\text { Ketepatan } \\
\text { format }\end{array}$} & \multicolumn{2}{|c|}{$\begin{array}{l}\text { Ketepatan } \\
\text { Indikator }\end{array}$} & \multicolumn{2}{|c|}{$\begin{array}{c}\text { Ketepatan } \\
\text { pengambilan } \\
\text { media }\end{array}$} & \multicolumn{2}{|c|}{$\begin{array}{l}\text { Ketepatan } \\
\text { langkah- } \\
\text { langkah } \\
\text { kegiatan }\end{array}$} & \multicolumn{2}{|c|}{$\begin{array}{l}\text { Ketepatan } \\
\text { penilaian }\end{array}$} \\
\hline & & $\mathrm{S}$ & $\mathrm{N}$ & $\mathrm{S}$ & $\mathrm{N}$ & $\mathrm{S}$ & $\mathrm{N}$ & $\mathrm{S}$ & $\mathrm{N}$ & $\mathrm{S}$ & $\mathrm{N}$ \\
\hline 1 & A & 3 & 60 & 3 & 60 & 4 & 80 & 4 & 80 & 3 & 60 \\
\hline 2 & B & 4 & 80 & 3 & 60 & 4 & 80 & 3 & 60 & 3 & 60 \\
\hline 3 & $\mathrm{C}$ & 4 & 80 & 3 & 60 & 3 & 60 & 3 & 60 & 4 & 80 \\
\hline 4 & $\mathrm{D}$ & 3 & 60 & 3 & 60 & 3 & 60 & 3 & 60 & 4 & 80 \\
\hline 5 & $\mathrm{E}$ & 3 & 60 & 3 & 60 & 3 & 60 & 3 & 60 & 3 & 60 \\
\hline 6 & $\mathrm{~F}$ & 3 & 60 & 3 & 60 & 4 & 80 & 4 & 80 & 3 & 60 \\
\hline 7 & $\mathrm{G}$ & 4 & 80 & 3 & 60 & 4 & 80 & 4 & 80 & 4 & 80 \\
\hline 8 & $\mathrm{H}$ & 3 & 60 & 4 & 80 & 4 & 80 & 4 & 80 & 4 & 80 \\
\hline 9 & I & 3 & 60 & 3 & 60 & 3 & 60 & 4 & 80 & 3 & 60 \\
\hline 10 & $\mathrm{~J}$ & 3 & 60 & 3 & 60 & 3 & 60 & 3 & 60 & 3 & 60 \\
\hline 11 & $\mathrm{~K}$ & 3 & 60 & 3 & 60 & 3 & 60 & 3 & 60 & 3 & 60 \\
\hline 12 & $\mathrm{~L}$ & 3 & 60 & 3 & 60 & 3 & 60 & 3 & 60 & 3 & 60 \\
\hline
\end{tabular}




\begin{tabular}{|c|c|c|c|c|c|c|c|c|c|c|c|}
\hline 13 & $\mathrm{M}$ & 3 & 60 & 3 & 60 & 3 & 60 & 3 & 60 & 3 & 60 \\
\hline 14 & $\mathrm{~N}$ & 3 & 60 & 4 & 80 & 4 & 80 & 3 & 60 & 4 & 80 \\
\hline 15 & $\mathrm{O}$ & 4 & 80 & 3 & 60 & 4 & 80 & 3 & 60 & 4 & 80 \\
\hline 16 & $\mathrm{P}$ & 3 & 60 & 4 & 80 & 4 & 80 & 3 & 60 & 4 & 80 \\
\hline 17 & $\mathrm{Q}$ & 3 & 60 & 3 & 60 & 3 & 60 & 4 & 80 & 3 & 60 \\
\hline 18 & $\mathrm{R}$ & 3 & 60 & 3 & 60 & 3 & 60 & 3 & 60 & 3 & 60 \\
\hline 19 & $\mathrm{~S}$ & 3 & 60 & 3 & 60 & 4 & 80 & 3 & 60 & 3 & 60 \\
\hline 20 & $\mathrm{~T}$ & 3 & 60 & 4 & 80 & 4 & 80 & 3 & 60 & 4 & 80 \\
\hline 21 & $\mathrm{U}$ & 3 & 60 & 4 & 80 & 4 & 80 & 3 & 60 & 4 & 80 \\
\hline 22 & $\mathrm{~V}$ & 4 & 80 & 4 & 80 & 3 & 60 & 4 & 80 & 4 & 80 \\
\hline 23 & $\mathrm{~W}$ & 3 & 60 & 4 & 80 & 4 & 80 & 3 & 60 & 4 & 80 \\
\hline 24 & $\mathrm{X}$ & 3 & 60 & 4 & 80 & 4 & 80 & 3 & 60 & 4 & 80 \\
\hline 25 & $\mathrm{Y}$ & 3 & 60 & 3 & 60 & 4 & 80 & 3 & 60 & 3 & 60 \\
\hline 26 & $\mathrm{Z}$ & 3 & 60 & 3 & 60 & 3 & 60 & 3 & 60 & 3 & 60 \\
\hline 27 & $\mathrm{AA}$ & 3 & 60 & 4 & 80 & 3 & 60 & 3 & 60 & 3 & 60 \\
\hline 28 & BB & 3 & 60 & 3 & 60 & 3 & 60 & 3 & 60 & 3 & 60 \\
\hline 29 & $\mathrm{CC}$ & 3 & 60 & 3 & 60 & 3 & 60 & 3 & 60 & 3 & 60 \\
\hline 30 & DD & 3 & 60 & 3 & 60 & 4 & 80 & 3 & 60 & 3 & 60 \\
\hline Rata-rata & 3,1 & 61,3 & 3,1 & 62 & 3,3 & 65,3 & 3,2 & 66,3 & 3,2 & 63,3 \\
\hline
\end{tabular}

Keterangan :

$\mathrm{S}=$ Skor

$\mathrm{N}=$ Nilai

Secara individu hasil observasi tentang kemampuan guru dalam menyusun agenda harian yang baik adalah sebagaimana tabel berikut :

Tabel 2 Data Hasil Observasi (Siklus I)

\begin{tabular}{|c|c|c|c|c|c|c|c|c|c|}
\hline \multirow{2}{*}{$\begin{array}{l}\mathrm{N} \\
\mathrm{O}\end{array}$} & \multirow{2}{*}{$\begin{array}{l}\mathrm{Na} \\
\mathrm{ma} \\
\text { Gur } \\
\mathrm{u}\end{array}$} & \multicolumn{5}{|c|}{ Agenda } & \multirow{2}{*}{$\begin{array}{l}\text { Sk } \\
\text { or }\end{array}$} & \multirow[t]{2}{*}{ Nilai } & \multirow{2}{*}{$\begin{array}{c}\text { Kateg } \\
\text { ori }\end{array}$} \\
\hline & & $\begin{array}{c}\text { Kete } \\
\text { patan } \\
\text { form } \\
\text { at }\end{array}$ & $\begin{array}{l}\text { Ketep } \\
\text { atan } \\
\text { Indika } \\
\text { tor }\end{array}$ & $\begin{array}{c}\text { Ketep } \\
\text { atan } \\
\text { penga } \\
\text { mbila } \\
\mathrm{n} \\
\text { media }\end{array}$ & $\begin{array}{c}\text { Kete } \\
\text { pata } \\
n \\
\text { lang } \\
\text { kah- } \\
\text { lang } \\
\text { kah } \\
\text { kegi } \\
\text { atan }\end{array}$ & $\begin{array}{c}\text { Ketepat } \\
\text { an } \\
\text { penilaia } \\
n\end{array}$ & & & \\
\hline 1 & A & 3 & 3 & 4 & 4 & 3 & 17 & 68 & $\mathrm{C}$ \\
\hline 2 & B & 4 & 3 & 4 & 3 & 3 & 17 & 68 & $\mathrm{C}$ \\
\hline 3 & C & 4 & 3 & 3 & 3 & 4 & 17 & 68 & $\mathrm{C}$ \\
\hline 4 & $\mathrm{D}$ & 3 & 4 & 4 & 3 & 4 & 18 & 72 & B \\
\hline
\end{tabular}




\begin{tabular}{|c|c|c|c|c|c|c|c|c|c|}
\hline 5 & $\mathrm{E}$ & 3 & 3 & 3 & 3 & 3 & 15 & 63 & $\mathrm{D}$ \\
\hline 6 & $\mathrm{~F}$ & 4 & 3 & 4 & 4 & 3 & 19 & 73 & B \\
\hline 7 & $\mathrm{G}$ & 3 & 3 & 4 & 4 & 4 & 19 & 73 & B \\
\hline 8 & $\mathrm{H}$ & 3 & 4 & 4 & 4 & 4 & 19 & 73 & B \\
\hline 9 & I & 3 & 3 & 3 & 4 & 3 & 16 & 64 & $\mathrm{C}$ \\
\hline 10 & $\mathbf{J}$ & 3 & 3 & 3 & 3 & 3 & 15 & 63 & $\mathrm{D}$ \\
\hline 11 & $\mathrm{~K}$ & 3 & 3 & 3 & 3 & 3 & 15 & 63 & $\mathrm{D}$ \\
\hline 12 & $\mathrm{~L}$ & 3 & 3 & 3 & 3 & 3 & 15 & 63 & $\mathrm{D}$ \\
\hline 13 & $\mathrm{M}$ & 3 & 3 & 3 & 3 & 3 & 15 & 63 & $\mathrm{D}$ \\
\hline 14 & $\mathrm{~N}$ & 3 & 4 & 4 & 3 & 4 & 18 & 72 & B \\
\hline 15 & $\mathrm{O}$ & 4 & 3 & 4 & 3 & 4 & 18 & 72 & B \\
\hline 16 & $\mathrm{P}$ & 3 & 4 & 4 & 3 & 4 & 18 & 72 & B \\
\hline 17 & $Q$ & 3 & 3 & 3 & 3 & 3 & 15 & 63 & D \\
\hline 18 & $\mathrm{R}$ & 3 & 3 & 3 & 3 & 3 & 15 & 63 & $\mathrm{D}$ \\
\hline 19 & $S$ & 3 & 4 & 4 & 3 & 4 & 18 & 72 & B \\
\hline 20 & $\mathrm{~T}$ & 3 & 4 & 4 & 3 & 3 & 18 & 72 & B \\
\hline 21 & $\mathrm{U}$ & 3 & 4 & 4 & 3 & 4 & 18 & 72 & B \\
\hline 22 & $\mathrm{~V}$ & 4 & 4 & 3 & 3 & 4 & 18 & 72 & B \\
\hline 23 & $\mathrm{~W}$ & 3 & 4 & 4 & 3 & 4 & 18 & 72 & B \\
\hline 24 & $X$ & 3 & 4 & 4 & 3 & 4 & 18 & 72 & B \\
\hline 25 & Y & 3 & 3 & 4 & 3 & 3 & 16 & 64 & D \\
\hline 26 & $\mathrm{Z}$ & 3 & 3 & 3 & 3 & 3 & 15 & 63 & $\mathrm{D}$ \\
\hline 27 & $\mathrm{AA}$ & 3 & 4 & 3 & 3 & 3 & 16 & 64 & $\mathrm{D}$ \\
\hline 28 & $\mathrm{BB}$ & 3 & 3 & 3 & 3 & 3 & 15 & 63 & $\mathrm{D}$ \\
\hline 29 & $\mathrm{CC}$ & 3 & 3 & 3 & 3 & 3 & 15 & 63 & $\mathrm{D}$ \\
\hline 30 & $\mathrm{DD}$ & 3 & 3 & 4 & 3 & 3 & 16 & 64 & $\mathrm{D}$ \\
\hline \multicolumn{2}{|c|}{$\begin{array}{l}\text { Rata- } \\
\text { rata }\end{array}$} & 3,2 & 3,4 & 3,5 & 3,2 & 3,4 & $\begin{array}{c}16, \\
7\end{array}$ & 67,6 & \\
\hline
\end{tabular}

Keterangan :

$\mathrm{S}=$ Skor

$\mathrm{N}=$ Nilai

\section{Siklus II}

Pada siklus II kegiatan yang dilakukan adalah mendiskusikan hambatan-hambatan yang dihadapi dalam penyusunan RPP kurikulum 2013 yang baik di siklus I. Peneliti menjelaskan lebih rinci tentang cara penyusunan administrasi akademik berupa RPP kurikulum 2013 yang baik.

Format penyusunan RPP kurikulum 2013 yang baik digunakan sesuai dengan format yang disepakati pada siklus I sehingga kegiatan selanjutnya adalah penyusunan RPP 
kurikulum 2013 dibimbing oleh peneliti dan dibantu oleh team teaching yaitu guru yang sudah mampu menyusun RPP kurikulum 2013 secara baik.

Hasil observasi tentang kemampuan guru pada siklus II adalah sebagai berikut :

Tabel 3 Data Hasil Observasi (Siklus II)

\begin{tabular}{|c|c|c|c|c|c|c|c|c|c|c|c|}
\hline \multirow[t]{3}{*}{ No } & \multirow{3}{*}{$\begin{array}{l}\text { Nama } \\
\text { Guru }\end{array}$} & \multicolumn{10}{|c|}{ Aspek yang di observasi } \\
\hline & & \multicolumn{2}{|c|}{$\begin{array}{c}\text { Ketepatan } \\
\text { format }\end{array}$} & \multicolumn{2}{|c|}{$\begin{array}{l}\text { Ketepatan } \\
\text { Indikator }\end{array}$} & \multicolumn{2}{|c|}{$\begin{array}{c}\text { Ketepatan } \\
\text { pengambilan } \\
\text { media }\end{array}$} & \multicolumn{2}{|c|}{$\begin{array}{l}\text { Ketepatan } \\
\text { langkah- } \\
\text { langkah } \\
\text { kegiatan }\end{array}$} & \multicolumn{2}{|c|}{$\begin{array}{l}\text { Ketepatan } \\
\text { penilaian }\end{array}$} \\
\hline & & $S$ & $\mathrm{~N}$ & $\mathrm{~S}$ & $\mathrm{~N}$ & $S$ & $\mathrm{~N}$ & $\mathrm{~S}$ & $\mathrm{~N}$ & $\mathrm{~S}$ & $\mathrm{~N}$ \\
\hline 1 & A & 5 & 100 & 4 & 80 & 5 & 100 & 5 & 100 & 4 & 80 \\
\hline 2 & B & 5 & 100 & 4 & 80 & 5 & 100 & 4 & 80 & 4 & 80 \\
\hline 3 & $\mathrm{C}$ & 5 & 100 & 4 & 80 & 4 & 80 & 4 & 80 & 5 & 100 \\
\hline 4 & $\mathrm{D}$ & 5 & 100 & 4 & 80 & 4 & 80 & 4 & 80 & 5 & 100 \\
\hline 5 & $\mathrm{E}$ & 5 & 100 & 4 & 80 & 4 & 80 & 4 & 80 & 4 & 80 \\
\hline 6 & $\mathrm{~F}$ & 5 & 100 & 4 & 80 & 4 & 80 & 4 & 80 & 4 & 80 \\
\hline 7 & G & 5 & 100 & 4 & 80 & 5 & 100 & 5 & 100 & 5 & 100 \\
\hline 8 & $\mathrm{H}$ & 5 & 100 & 5 & 100 & 5 & 100 & 5 & 100 & 5 & 100 \\
\hline 9 & $\mathrm{I}$ & 5 & 100 & 4 & 80 & 4 & 80 & 5 & 100 & 4 & 80 \\
\hline 10 & $\mathbf{J}$ & 5 & 100 & 4 & 80 & 4 & 80 & 4 & 80 & 4 & 80 \\
\hline 11 & $\mathrm{~K}$ & 5 & 100 & 4 & 80 & 4 & 80 & 4 & 80 & 5 & 100 \\
\hline 12 & $\mathrm{~L}$ & 5 & 100 & 4 & 80 & 4 & 80 & 4 & 80 & 5 & 100 \\
\hline 13 & $\mathrm{M}$ & 5 & 100 & 4 & 80 & 4 & 80 & 4 & 80 & 4 & 80 \\
\hline 14 & $\mathrm{~N}$ & 5 & 100 & 4 & 80 & 4 & 80 & 4 & 80 & 5 & 100 \\
\hline 15 & $\mathrm{O}$ & 5 & 100 & 4 & 80 & 4 & 80 & 4 & 80 & 5 & 100 \\
\hline 16 & $\mathrm{P}$ & 5 & 100 & 4 & 80 & 4 & 80 & 4 & 80 & 4 & 80 \\
\hline 17 & $\mathrm{Q}$ & 5 & 100 & 4 & 80 & 4 & 80 & 4 & 80 & 4 & 80 \\
\hline 18 & $\mathrm{R}$ & 5 & 100 & 4 & 80 & 5 & 100 & 5 & 100 & 5 & 100 \\
\hline 19 & $S$ & 5 & 100 & 4 & 80 & 4 & 80 & 4 & 80 & 5 & 100 \\
\hline 20 & $\mathrm{~T}$ & 5 & 100 & 4 & 80 & 4 & 80 & 4 & 80 & 5 & 100 \\
\hline 21 & $\mathrm{U}$ & 5 & 100 & 4 & 80 & 4 & 80 & 4 & 80 & 4 & 80 \\
\hline 22 & $\mathrm{~V}$ & 5 & 100 & 4 & 80 & 4 & 80 & 4 & 80 & 4 & 80 \\
\hline 23 & $\mathrm{~W}$ & 5 & 100 & 4 & 80 & 5 & 100 & 5 & 100 & 5 & 100 \\
\hline 24 & $\mathrm{X}$ & 5 & 100 & 4 & 80 & 4 & 80 & 4 & 80 & 5 & 100 \\
\hline 25 & $\mathrm{Y}$ & 5 & 100 & 4 & 80 & 4 & 80 & 4 & 80 & 4 & 80 \\
\hline 26 & $\mathrm{Z}$ & 5 & 100 & 4 & 80 & 4 & 80 & 4 & 80 & 5 & 100 \\
\hline 27 & AA & 5 & 100 & 4 & 80 & 4 & 80 & 4 & 80 & 5 & 100 \\
\hline 28 & BB & 5 & 100 & 4 & 80 & 4 & 80 & 4 & 80 & 4 & 80 \\
\hline 29 & $\mathrm{CC}$ & 5 & 100 & 4 & 80 & 4 & 80 & 4 & 80 & 4 & 80 \\
\hline 30 & DD & 5 & 100 & 4 & 80 & 5 & 100 & 5 & 100 & 5 & 100 \\
\hline
\end{tabular}




\begin{tabular}{l|l|l|l|l|l|l|l|l|l|l|}
\hline Rata-rata & 5 & 100 & 4,03 & 82 & 4,3 & 88 & 4,2 & 88 & 4,5 & 88 \\
\hline Keterangan : \\
$\mathrm{S}=$ Skor \\
$\mathrm{N}=$ = Nilai
\end{tabular}

Secara Individu hasil observasi tentang kemampuan guru dalam menyusun RPP kurikulum 2013 yang baik pada siklus II adalah sebagaimana tabel berikut :

Tabel 4 Data Hasil Observasi (Siklus II)

\begin{tabular}{|c|c|c|c|c|c|c|c|c|c|}
\hline \multirow{2}{*}{$\begin{array}{l}\mathrm{N} \\
\mathrm{O}\end{array}$} & \multirow{2}{*}{$\begin{array}{l}\mathrm{Na} \\
\mathrm{ma} \\
\text { Gur } \\
\mathrm{u}\end{array}$} & \multicolumn{5}{|c|}{ Indikator yang dinilai } & \multirow{2}{*}{$\begin{array}{l}\text { Sk } \\
\text { or }\end{array}$} & \multirow{2}{*}{ Nilai } & \multirow{2}{*}{$\begin{array}{l}\text { Kate } \\
\text { gori }\end{array}$} \\
\hline & & $\begin{array}{l}\text { Kete } \\
\text { patan } \\
\text { form } \\
\text { at }\end{array}$ & $\begin{array}{l}\text { Ketep } \\
\text { atan } \\
\text { Indika } \\
\text { tor }\end{array}$ & $\begin{array}{c}\text { Ketep } \\
\text { atan } \\
\text { penga } \\
\text { mbila } \\
\text { n } \\
\text { media }\end{array}$ & $\begin{array}{c}\text { Kete } \\
\text { pata } \\
\mathrm{n} \\
\text { lang } \\
\text { kah- } \\
\text { lang } \\
\text { kah } \\
\text { kegi } \\
\text { atan }\end{array}$ & $\begin{array}{c}\text { Ketepata } \\
\mathrm{n} \\
\text { penilaian }\end{array}$ & & & \\
\hline 1 & $\mathrm{~A}$ & 5 & 4 & 5 & 5 & 4 & 23 & 92 & A \\
\hline 2 & B & 5 & 4 & 5 & 4 & 4 & 22 & 88 & B \\
\hline 3 & $\mathrm{C}$ & 5 & 4 & 4 & 4 & 5 & 22 & 88 & B \\
\hline 4 & $\mathrm{D}$ & 5 & 5 & 5 & 4 & 5 & 24 & 93 & A \\
\hline 5 & $\mathrm{E}$ & 5 & 4 & 4 & 4 & 4 & 21 & 87 & $\mathrm{~B}$ \\
\hline 6 & $\mathrm{~F}$ & 5 & 4 & 5 & 5 & 5 & 24 & 95 & $\mathrm{~A}$ \\
\hline 7 & $\mathrm{G}$ & 5 & 4 & 5 & 5 & 5 & 24 & 95 & $\mathrm{~A}$ \\
\hline 8 & $\mathrm{H}$ & 5 & 5 & 5 & 5 & 5 & 25 & 100 & $\mathrm{~A}$ \\
\hline 9 & I & 5 & 5 & 4 & 5 & 4 & 23 & 92 & $\mathrm{~A}$ \\
\hline 10 & $\mathbf{J}$ & 5 & 5 & 4 & 4 & 4 & 22 & 88 & B \\
\hline 11 & $\mathrm{~K}$ & 5 & 4 & 4 & 4 & 5 & 22 & 88 & B \\
\hline 12 & $\mathrm{~L}$ & 5 & 4 & 4 & 4 & 5 & 22 & 88 & B \\
\hline 13 & $\mathrm{M}$ & 5 & 4 & 4 & 4 & 4 & 21 & 87 & B \\
\hline 14 & $\mathrm{~N}$ & 5 & 4 & 4 & 4 & 5 & 22 & 88 & B \\
\hline 15 & $\mathrm{O}$ & 5 & 4 & 4 & 4 & 5 & 22 & 88 & B \\
\hline 16 & $\mathrm{P}$ & 5 & 4 & 4 & 4 & 4 & 21 & 87 & B \\
\hline 17 & $\mathrm{Q}$ & 5 & 4 & 4 & 4 & 4 & 21 & 87 & B \\
\hline 18 & $\mathrm{R}$ & 5 & 4 & 5 & 5 & 5 & 24 & 95 & $\mathrm{~A}$ \\
\hline 19 & $S$ & 5 & 4 & 4 & 4 & 5 & 21 & 87 & B \\
\hline 20 & $\mathrm{~T}$ & 5 & 4 & 4 & 4 & 5 & 22 & 88 & B \\
\hline 21 & $\mathrm{U}$ & 5 & 4 & 4 & 4 & 4 & 21 & 87 & B \\
\hline 22 & $\mathrm{~V}$ & 5 & 4 & 4 & 4 & 4 & 21 & 87 & B \\
\hline 23 & $\mathrm{~W}$ & 5 & 4 & 5 & 5 & 5 & 24 & 95 & $\mathrm{~A}$ \\
\hline
\end{tabular}




\begin{tabular}{|l|c|c|c|c|c|c|c|c|c|}
\hline 24 & $\mathrm{X}$ & 5 & 4 & 4 & 4 & 5 & 22 & 88 & $\mathrm{~B}$ \\
\hline 25 & $\mathrm{Y}$ & 5 & 4 & 4 & 4 & 4 & 21 & 87 & $\mathrm{~B}$ \\
\hline 26 & $\mathrm{Z}$ & 5 & 4 & 4 & 4 & 5 & 22 & 88 & $\mathrm{~B}$ \\
\hline 27 & $\mathrm{AA}$ & 5 & 4 & 4 & 4 & 5 & 22 & 88 & $\mathrm{~B}$ \\
\hline 28 & $\mathrm{BB}$ & 5 & 4 & 4 & 4 & 4 & 21 & 87 & $\mathrm{~B}$ \\
\hline 29 & $\mathrm{CC}$ & 5 & 4 & 4 & 4 & 4 & 21 & 87 & $\mathrm{~B}$ \\
\hline 30 & $\mathrm{DD}$ & 5 & 4 & 5 & 5 & 5 & 24 & 95 & $\mathrm{~A}$ \\
\hline $\begin{array}{l}\text { Rata- } \\
\text { rata }\end{array}$ & $\mathbf{5}$ & $\mathbf{4 , 1}$ & $\mathbf{4 , 3}$ & $\mathbf{4 , 3}$ & $\mathbf{4 , 6}$ & $\mathbf{2 3}$ & $\mathbf{9 1 , 8}$ & \\
\hline
\end{tabular}

Keterangan :

$\mathrm{S}=$ Skor

$\mathrm{N}=$ Nilai

\section{B. Pembahasan}

Pembahasan hasil penelitian merupakan suatu kajian terhadap hasil temuan yang ada hubungannya dengan jawaban permasalahan penelitian yang telah dinyatakan dalam bab sebelumnya. Adapun pembahasan hasil penelitian akan diuraikan sebagai berikut :

1. Siklus I

Berdasarkan tabel 4 tersebut di atas, hasil observasi dari siklus I ini menunjukkan bahwa kemampuan guru dalam menyusun RPP kurikulum 2013yang baik adalah diuraikan sebagaimana berikut :

a. Rata-rata kemampuan guru dalam menyusun RPP kurikulum 2013 dalam ketepatan format adalah 61,3. Hal ini menunjukkan bahwa kemampuan guru dalam menyusun RPP kurikulum 2013dalam pembuatan format adalah kurang.

b. Rata-rata kemampuan guru dalam menyusun RPP kurikulum 2013 dalam ketepatan indikator adalah 62. Hal ini menunjukkan bahwa kemampuan guru dalam menyusun RPP kurikulum 2013 pada ketepatan indikator adalah kurang.

c. Rata-rata kemampuan guru dalam menyusun RPP kurikulum 2013 dalam ketepatan pengambilan media adalah 68. Hal ini menunjukkan bahwa kemampuan guru dalam menyusun RPP kurikulum 2013 dalam ketepatan pengambilan media adalah cukup.

d. Rata-rata kemampuan guru dalam menyusun RPP kurikulum 2013 dalam ketepatan langkah-langkah kegiatan adalah 65,3, hal ini menunjukkan guru dalam menyusun RPP kurikulum 2013 dalam langkah-langkah dianggap cukup.

e. Rata-rata guru dalam menyusun RPP kurikulum 2013 dalam ketepatan penilaian adalah 66,3, hal ini menunjukkan guru dalam menyusun RPP kurikulum 2013 dalam ketepatan penilaian adalah cukup.

Berdasarkan tabel 4.2 tersebut di atas, hasil observasi dari siklus I ini menunjukkan bahwa kemampuan guru dalam menyusun RPP kurikulum 2013yang baik adalah diuraikan sebagaimana berikut : 
a. Nilai kemampuan guru yang mendapatkan nilai "A" dalam menyusun RPP kurikulum 2013 yang baik adalah 0 atau $0 \%$.

b. Nilai kemampuan guru yang mendapatkan nilai "B" dalam menyusun RPP kurikulum 2013yang baik adalah 13 orang atau 43,3\%.

c. Nilai kemampuan guru yang mendapatkan nilai "C" dalam menyusun RPP kurikulum 2013 yang baik adalah 4 orang atau 13,3\%.

d. Nilai kemampuan guru yang mendapatkan nilai " $D$ " dalam menyusun RPP kurikulum 2013 yang baik adalah 13 orang atau 43,3\%.

Berdasarkan tabel tersebut di atas, secara umum hasil observasi dari siklus I ini menunjukkan bahwa kemampuan guru dalam menyusun RPP kurikulum 2013 yang baik belum menunjukkan hasil yang memuaskan, ini terlihat dari 30 orang yang penulis teliti masih belum ada yang mendapatkan nilai "A", bahkan masid ada yang mendapatkan nilai kurang yaitu 13 orang atau 43,3\% dari jumlah 30 orang.

Memperhatikan hasil siklus I peneliti melakukan refleksi terhadap hasil yang diperoleh. Hambatan-hambatan yang ditemukan pada siklus I seperti efektivitas penyampaian informasi-informasi tentang cara penyusunan administrasi akademik berupa RPP kurikulum 2013 yang baik masih bersifat umum terbukti guru belum mencapai nilai maksimal. Oleh karena itu, perlu dilakukan pembinaan selanjutnya. Hal-hal yang menjadi hambatan pada siklus I ini, akan diperbaiki dan disempurnakan pada siklus II.

\section{Siklus II}

Berdasarkan tabel 4.3 tersebut di atas, hasil observasi dari siklus II ini menunjukkan bahwa kemampuan guru dalam menyusun RPP kurikulum 2013 yang baik adalah sebagai berikut :

a. Rata-rata kemampuan guru dalam menyusun RPP kurikulum 2013 dalam ketepatan format adalah 100. Hal ini menunjukkan bahwa kemampuan guru dalam menyusun RPP kurikulum 2013dalam pembuatan format adalah Sangat Baik.

b. Rata-rata kemampuan guru dalam menyusun RPP kurikulum 2013 dalam ketepatan indikator adalah 82. Hal ini menunjukkan bahwa kemampuan guru dalam menyusun RPP kurikulum 2013 pada ketepatan indikator adalah Baik.

c. Rata-rata kemampuan guru dalam menyusun RPP kurikulum 2013 dalam ketepatan pengambilan media adalah 88. Hal ini menunjukkan bahwa kemampuan guru dalam menyusun RPP kurikulum 2013 dalam ketepatan media adalah Baik.

d. Rata-rata kemampuan guru dalam menyusun RPP kurikulum 2013 dalam ketepatan langkah-langkah kegiatan adalah 88, hal ini menunjukkan guru dalam menyusun RPP kurikulum 2013 dalam ketepatan langkah-langkah kegiatan dianggap Baik. 
e. Rata-rata guru dalam menyusun RPP kurikulum 2013 dalam ketepatan penilaian adalah 88 , hal ini menunjukkan guru dalam menyusun RPP kurikulum 2013 dalam ketepatan penilaian adalah Baik.

Berdasarkan tabel 4.4 di atas, hasil observasi dari siklus II ini menunjukkan bahwa kemampuan guru dalam menyusun RPP kurikulum 2013 yang baik adalah diuraikan sebagaimana berikut :

a. Nilai kemampuan guru yang mendapatkan nilai "A" dalam menyusun RPP kurikulum 2013 yang baik adalah 9 orang atau 30\%.

b. Nilai kemampuan guru yang mendapatkan nilai "B" dalam menyusun RPP kurikulum 2013 yang baik adalah 21 orang atau $70 \%$.

Berdasarkan tabel tersebut di atas, secara umum hasil observasi dari siklus II ini menunjukkan bahwa kemampuan guru dalam menyusun RPP kurikulum 2013 yang baik adalah baik sekali, hal ini ditunjukkan dari jumlah 30 oarng guru 21 orang mendapatkan nilai "A" atau 70\% sedangkan sisanya mendapatkan nilai "B" yaitu 9 orang atau $30 \%$

Dengan demikian jelas telah terjadi peningkatan kemampuan guru dalam menyusun RPP kurikulum 2013 yang baik, hal ini sebagaimana terlihat dalam tabel 4.5 berikut :

Tabel 5 Data Hasil Observasi (Siklus I dan Siklus II)

\begin{tabular}{|c|c|c|c|c|}
\hline No & $\begin{array}{c}\text { Nilai } \\
\text { kemampuan } \\
\text { Guru }\end{array}$ & Siklus I (\%) & Siklus II(\%) & Keterangan \\
\hline 1 & A & 0 & 30 & Baik sekali \\
\hline 2 & B & 43,3 & 70 & Baik \\
\hline 3 & C & 13,3 & 0 & Cukup \\
\hline 4 & D & 43,3 & 0 & Kurang \\
\hline
\end{tabular}

\section{Kesimpulan}

Berdasarkan temuan-temuan yang diperoleh dari hasil pengolahan dan analisis data penelitian ini, maka dapat disimpulkan bahwa pembinaan administrasi akademik berupa penyusunan RPP kurikulum 2013 yang baik sangat signifikan. Dengan kata lain melalui pembinaan pengawas kepada guru mampu meningkatkan kemampuan akademik guru dalam bentuk penyusunan RPP kurikulum 2013 dalam mencapai sasaran kinerja.

\section{DAFTAR PUSTAKA}

Ahmadi, Abu dan Joko Tri Prasetya. 1997. Pembelajaran Anak Bagi BermasalahJakarta, Rinekacipta. 
Jurnal At Tadbir STAI Darul Kamal NW Kembang kerang NTB

Volume 5 No 1 Tahun 2021

P-ISSN : 2580-3433

E-ISSN : 2715-7210

https://journal.staidk.ac.id/index.php/tadbir

Akdon. 2002. Identifikasi Faktor-faktor Kemampuan Manajerial Yang Diperlukan Dalam Implementasi School Based Management (SBM) Dan Implikasinya Terhadap Program Pembinaan Kepala Madrasah. Bandung: Jurnal Adpend UPI.

Ali, M. 2004. Strategi Penelitian Pendidikan. Bandung: Angkasa.

Arifin, E. 2003. Dasar-Dasar Penulisan Karangan Ilmiah. Jakarta: PT. Gramedia Widiasarana Indonesia.

Arikunto, S. 2002. Prosedur Penelitian Suatu Pendekatan Praktek. Jakarta: Rineka Cipta.

Arikunto, Suharsimi. 2006. Prosedur Penelitian Suatu Pendekatan Praktik. Jakarta: Rineka Cipta.

Barret, 2000. Test Your Own Aptitude. Jakarta : Gaya Media Pratama, h. 65.

Depdiknas. 2003. Program Kegiatan Belajar di MI. Jakarta.

Mulyasa, E. 2003. Menjadi Kepala Madrasah Profesional Dalam Konteks Menyukseskan Manajemen Berbasis Sekolah dan Kurikulum Berbasis Kompetensi. Bandung: PT. Remaja Rosdakarya.

S. Margono, 2004. Metodologi Penelitian Pendidikan. Jakarta: PT. Rineka Cipta.

Santoso, S. 2002. Pendidikan di MI. Jakarta: Citra Pendidikan.

Solehuddin, M. 2000. Konsep Dasar Pendidikan Pra Sekolah. Bandung: Fakultas Ilmu Pendidikan UPI.

Subana dan Sunarti. 2001. Strategi Belajar Mengajar Bahasa Indonesia. Bandung, Alfabeta.

Subino. 2001. Bimbingan, Rancangan, Pelaksanaan, Analitik dan Penulisan. Bandung: ABA Yapari.

Sudjana, N. 1991. Tuntunan Penulisan Karya Ilmiah. Bandung: Sinar Baru.

Sugiarto, D.S. 2000. Metode Statistik Untuk Bisnis dan Ekonomi. Jakarta: PT. Gramedia Pustaka Utama.

Sugiyono. 1997. Statistik Untuk Penelitian. Bandung: Alfabeta. 